\title{
Marketing Strategy Formulation for Organic Restaurants in Sanur Tourism Area of Bali
}

\author{
I Gusti Ayu Dewi Hendriyani, I Nyoman Rinala and Putu Mira Astuti Pranadewi \\ Hospitality Department \\ Sekolah Tinggi Pariwisata Nusa Dua Bali \\ Nusa Dua Bali, Indonesia \\ dewi.hendriyani2@gmail.com
}

\begin{abstract}
The growth of tourism industry in Sanur Tourism Area has stimulated the growth of restaurant business on this area. Organic food is becoming most people concern for their health and begin as a lifestyle. There were around 7 organic restaurants on the Sanur Tourism Area. The objectives of this research were investigating the strength and threat factors of organic restaurant industry in this area, and developing proper marketing strategy formulation. This research was undertaken between August and November, 2015. The total populations were 7 organic restaurants, meanwhile total number of respondents were 112, who consist of 105 visitors and 7 restaurant managers. The analysis tools utilized in this research were IFE analysis, EFE analysis, Internal-External Matrix Analysis, Position Matrix Analysis, and SWOT Analysis Matrix. The findings of this research were as follows: first, internal marketing variables of restaurant industries consist of 18 strengths and 1 weakness indicators; second, external marketing variables consists of 7 opportunities and 1 threats indicator; third, the combination of Internal-External Matrix and Position Matrix Analysis show that the position was at Cell I (grow and build strategy) and meanwhile Position Matrix Analysis Pointed at Quadran I (Grow and Develop Strategy). Finally, based on the SWOT Analysis Matrix,the proper marketing strategy formulation showed that organic restaurants in Sanur Tourism Area were supposed to implement Grand/ Main Strategy (market penetration, product development, and market development strategy) and Alternatif Strategy (SO, WO, ST, and WT Strategy)
\end{abstract}

Keywords-Marketing Strategy, Organic Restaurant, Sanur Tourism Area, SWOT Analysis

\section{INTRODUCTION}

The hospitality industry is usually identified by its output of products which satisfy the demand for foods, drinks and accommodation away from home. The industry is often split into the accommodation and foodservice industries. Restaurants are, however, primary retailers of 'foodservice experiences'. Previous studies reported that restaurant services were a blend of tangible and intangible components. They are subjectively experienced processes where production and consumption activities take place simultaneously. Customers are the actual agents or stakeholders for determining or best judging the success of any product service offered by restaurant. In this case, customer satisfaction is a key success of a profitable restaurant.

In profit oriented restaurant business, marketing is aimed at meeting customer demand, usually in competition with other restaurants, for profit. In order to create the competitive advantage necessary to achieve growth, Porter (1990) suggests that firms (restaurants) should adopt one of three generic competitive strategies, such as cost leadership strategy, focus strategy, and differentiation strategy. For many countries in Asia, cuisine have become major pull factors to attract tourists (Enright \& Newton, 2005). In recent years, there is a new form of tourism which regards food-tasting as major or only purpose, like food and wine tourism, culinary tourism, gastronomy tourism, food festival and other related-food activity (Hall \& Sharples, 2003; Kivela \& Crotts, 2005).

Bali as a major tourist destination in Indonesia, has become a barometer of the tourism development in Indonesia. Besides being very popular among foreign tourists, Bali is also a major destination for domestic tourists to vacation, conduct business and other activities. Statistics official news (Biro Pusat Statistik-Bali) Bali Tourism Development in the period from January to December 2015, the cumulative foreign tourists coming to Bali are 3.766 .638 people. For the period of origin of foreign tourists coming to Bali most nationals of Australia $(26.33 \%)$, China $(15.57 \%)$, Malaysia $(5.99 \%)$, Japan $(5.77 \%)$, and Singapore $(4.77 \%)$.

Healthy lifestyle is now the trend for the middle and upper classes throughout the world. Public awareness of the importance of adopting a healthy lifestyle is increasing from time to time. One indicator that can be seen is an increase in the consumption of organic food. Consuming organic food can serve as a cleanser of toxins - toxins in the human body (antioxidant) organic foods provide nutrients to the body, activate cells - the cells of the body and also at the same time maintaining the balance of health (Kartini, 2011). Organic food can be defined as food produced without chemical fertilizers and without pesticides (Prof. Dr. F. G. Winarno quoted Indonesian Culinary Website, 2011). The organic food industry has experienced rapid growth since the decade of the 1990s, where since 1990 the sales of organic food in the developed countries has increased every year an average of $20 \%$ (Godsey, 2010: 1). The term organic food is often associated as a product 
of fruits and vegetables, instead of poultry, beef, or other sources of animal protein products (Godsey, 2010:2).

The high demand for organic food is increasing the number of organic farms in the world. In the Asian region, the country with the largest organic farms are India and China. (Pranasari 2004, November). In 1998, according to a survey conducted in Europe found that $94 \%$ of respondents buy organic products because they are very concerned with the health of themselves and their family members (Eureka Indonesia Foundation website, 2009). Since the last few decades, the world community care will farm more healthy and growing global environmental issues through government support and through the campaign - a campaign on the importance of lifestyle and a healthier diet (Griffiths, 2010). Given this form of caring societies produce food without destroying resources - natural resources such as air, water, and soil. Organic food is becoming one of the business comunity in preserving the environment, because the food does not use materials - hazardous materials such as pesticides. Consuming organic food has been believed by the world community can support the preservation of the environment and contribute to reducing global warming. This opinion is supported by Davis, (2006: 1), which states: "This rapid growth of organic food industry may be traced to Increased consumer confidence in organic foods, such as well as to concerns about possible health risks and environmental impacts of conventional food production methods. Green consumerism is a continuation of global consumerism movement that began with the awareness of consumers of their rights to obtain products that are feasible, safe, and environmentally-friendly products which is getting stronger. Furthermore, the desired product is not really green, but a product that can reduce the level of damage to the environment and the human body are consumed (Gran in Rizky, 2013). With the awareness that it is expected that companies can implement environmental issues as one of their marketing strategy.

Bali island whose economy is driven by agriculture and tourism, has a huge potential to combine or synergize agriculture products are made from organic restaurant. Synergies are agriculture and tourism potential to encourage local people and tourists to enjoy organic food products that are environmentally friendly. Likewise, the high interest of the global community in organic food, is expected to impact on the restaurant business in Bali, especially in Sanur Tourism Area. Specific benefits obtained by the tourists and the restaurants that offer organic food is the traveler can consume natural healthy food free of chemicals, antibiotics and hormones fat at the same time protecting the agricultural environment of the use of chemicals (pesticides, fertilizers), while the restaurant gain business advantage of its business based organic agricultural products produced by the surrounding environment that cultivated by local farmers communities.

In Sanur Tourism Area there are 7 restaurants were considered as organic restaurants because they sell most organic product. That restaurants are Manik Organik (Danau Tamblingan Street 85), Dusk Blue (Duyung Street 3), Malaika Secret Garden (Arogya Corner, Mertasari Street), Happy Laksmi (Tukad Yeh Aya Street 137), Nitai Pizz (Tukad Pancoran Street 2), Loving Hut Denpasar (Sudirman Agung Street) and Mila's Warung (Batursari 70) . Sources: internet survey (2015). Based on this data, there were considerable opportunities for organic food businesses to the efforts in both in terms of product quality, hygiene, food safety, packaging, promotion and marketing, so that the organic food products sold better and could ultimately provide satisfaction to tourists. Growing awareness of travelers to eat healthy foods produced from chemical-free agriculture should directly or indirectly support the growing number of organic restaurants and consumption of organic food in Bali.

At this time there are some marketing difficulties faced by the restaurant business that sells food made from organic food stuff, among other things: the price of the material is more expensive, material size is smaller, not all travelers aware about the importance of healthy food which are free of chemicals and genetic engineering, and some tourists are price oriented. The impact is the difficulty restaurant market products in an effort to attract new market segments in addition to broader segments of the market which has been a loyal customer of an organic restaurant. On the other hand, the appeal of Bali with the national strategic tourism area as a destination for foreign tourists and domestic tourists continues to increase. Based on the results of preliminary interviews with some organic restaurant managers, can know the problems experienced in marketing organic restaurant in Sanur tourism area.

Based on those phenomena, this study would like to explore how organic restaurants in Sanur tourism area, creating their marketing strategies to attract new market segments, increase customers satisfaction and loyalty, increase sales and profit, by identifying strength, weakness, opportunity, and threat factors of internal and external marketing environment. Based on the above discussion on marketing strategies the following research questionnaire posed:

a. What are the strength and weakness points of organic restaurants in Sanur Tourism Area?

b. What are the opportunity and threat points of organic restaurants?

c. How is the proper marketing strategy formulation of organic restaurants in Sanur Tourism area in an effort to increase sales volume?

The objectives of this study are three folds. The first is that this study intends to explore the strength and weakness points of organic restaurants in Sanur tourism area. Second, this study also intends to explore the opportunity and threat points of organic restaurants in Sanur tourism area. And last, this study aimed at investigatying the proper marketing strategy formulation for organic restaurants in Sanur area. Based on the findings of this study suggestions would be made to tourism business stakeholders. It is hoped that this study would contribute the following:

a. Providing empirical evidence of internal and external marketing environment of organic restaurants in Sanur tourism area;

b. Providing empirical evidence on the marketing strategy formulation of organic restaurants;

c. Gaining the insight how organic restaurants in Sanur tourism area formulating grand and alternative 
marketing strategies as efforts to attract more customers and increase sales.

\section{LITERATURE REVIEW}

Research conducted by Sangkumchaliang and Huang (2012) entitled "Consumers' Perceptions and Attitudes of Organic Food Products in Northern Thailand." Indicates that the respondent's main motivation for buying organic food products are organic food products healthier and more environmentally friendly. The main obstacle in the sales of organic food products is the availability of information and awareness of consumers themselves. Thio (2008) in the journal titled Consumer Perceptions on Organic Food in Surabaya found that in general consumers in Surabaya have a good perception of organic food. This study uses 380 respondents were divided into two categories namely the respondents who had purchased organic food and respondents who never buy organic food. Respondents who had purchased organic food in mind that $88.2 \%$ of respondents have an interest to re-purchase the organic food and by $11.8 \%$ of respondents expressed no interest in re-purchase. Amalina (2010) investigated the User Perceptions toward Food oganic, found that of 350 respondents the majority of respondents agree that organic food is healthier because it is free of pesticide residues (89.4\%), more environmentally friendly $(84.5 \%)$, and higher quality $(62.0 \%)$. Some $57.4 \%$ of respondents willing to pay more for food oganik. Overall all respondents have a good perception about organic foods, although there are respondents who are not willing to pay more for organic food. Harper and Makatouni (2002) conducted research on consumer perceptions of organic food production and organic farming are carried out in the UK. Focus Group Discussion was held to identify the core beliefs and attitudes of consumers towards organic food made by buyers of organic food and non-organic food buyers. The results of this study found that although health and food safety be the main motivation for purchasing organic food, consumers also consider factors that a good way of raising animals (animal welfare) is also significant in organic food purchase decisions.

According to Winter and Davis (2006) in the journal entitled Organic Foods found that the popularity of organic foods has increased dramatically due to several things. Consumers buy organic food may be due to several reasons, among others: consumer perceptions of organic food is more beneficial to the environment, animal health, and safety of workers, and the perception that organic foods are safer and more nutritious. Review of the FGD found that organic fruits and vegetables containing pesticide lower than conventional fruits and vegetables, which in turn led to lower also pesticide residues. Research of Ahmad (2010) with the title of Organic Food: A Study of Demographic Characteristics and Factors Influencing Purchase Intention Among Consumers in Klang Valley, Malaysia found that the purchase intention of organic products is strongly influenced by consumers' perceptions of the value of purchases of organic products as well as confidence in the safety and health of products organic. Respondents in this study divided into two categories buyers of organic products and non-organic product buyers. Among the respondents who buy organic products, the majority of consumers believe that organic food is healthier, tastier and more sustainable than conventional food.

According Dardak, et al (2009) who conducted the study with the title Consumers, Perceptions, Consumption and Preference on Organic Product: Malaysian Perspective, found that more than $90 \%$ of respondents recognize and understand organic products. Respondents associate organic products with chemical-free foods, foods healthier and more natural. This research nationwide survey in Malaysia by using 625 respondents. Most respondents (93\%) believe that organic products can be found in vegetables, in fruit $(68 \%)$ and meat $(17 \%)$. Factors - factors that affect the respondent to consume organic food, among others: 1). the perception that organic foods are safer and better for health $(83 \%), 2)$. The quality of organic food is better (42\%), and 3). Organic food contributes to protecting the environment. Research conducted by Suharjo, et al (2013). This study found that there is a barrier in the purchase of organic food products such as: organic food can only be obtained on the spot - a particular place, are more expensive than conventional foods, some products are not always available, quickly expired, it is difficult to distinguish the product non-organic, it is difficult to get in traditional markets, and little information about the advantages of organic products. At respondents who did not consume organic products, some of them are interested in trying or even to be consumed regularly as they know the benefits, some do not want to try even though they know the benefits due to the price of organic products is relatively expensive. The most important research findings from this study is the respondent's perception of organic foods is that they can not directly feel the benefits of organic food for health, but the majority of these respondents consider both the benefits of organic products.

\section{A. Restaurant Marketing Mix and Strategy}

Marketing is about solving guest problem, and happy guests result in free marketing as word-of-mouth advertising. Morrison (2002: 205), defined marketing strategy is the selection of a course of action from among several alternatives that involves specific customer groups, communication methods, distribution channels, and pricing structures. Furthermore, Varadarajan, (2010) conceptualized marketing strategy as an organization's crucial choices concerning products, markets, marketing activities and marketing resources in the creation, communication and/or delivery of products that offer value to customers in exchanges with the organization.

Marketing strategy will also locate the restaurant in relation to competition regarding price, the food, and service offered, atmosphere, and convenience (Walker, 2008: 113). Marketing strategy is the way the restauranteur accomplishes the goals set for restaurant. The strategy is the game plan for attaining determined goals. SWOT or TOWS analysis is a strategic planning and marketing strategies used for regional assessment. In fact, it is an instrument which is generally used to place the result of analysis of external pressure beside the internal capacities (Miandehi and Masrouri (2013). SWOT Analysis can provide a good basis for assessment and strategy formulation, even though it is often left only at the level of pinpointing the issues and describing them in general terms 
(Kangas at al., 2003; Ganjali et al., 2014). SWOT matrix helps managers develop four types of strategies respectively; SO (strengths-opportunities) strategies, WO (weaknessesopprtunities) strategies, ST (strengths-threats) strategies, and WT (weaknesses-threats) strategies (Ganjali, et al., 2014). SO strategies use a firm's internal strengths to take advantage of external opportunities. WO strategies overcome internal weaknesses by capitalizing on external opportunities. ST strategies use a firm's strengths to avoid or reduce the impact of external threats. WT strategies are defensive tactics directed at reducing internal weaknesses and avoiding environmental threats (Weihrich, 1982). Dwyer and Tanner, 2002 defined SWOT or TOWS is analysis as a strategic planning tool used to evaluate the different factors in situation analysis. Weihrich, 1982 conceptualized SWOT analysis involves systematic thinking and comprehensive diagnosis of factors relating to a new product, technology, management, or planning. SWOT analysis is one of marketing techniques which stands for strengths, weaknesses, opportunities, and threats (Walker, 2008: 113). Strengths and weaknesses focus on internal factors and can overtime, be controlled by management. Opprtunities and threats are external factors. Obviously, strengths and opportunities are issues that affect a company in a positive way, while weaknesses and threats have negative impact. This analysis aims to identify the main internal and external factors to achieve the goal (Pahl and Richter, 2009). SWOT analysis is an effective tool for analyzing internal and external environtments in order to attain systematic approaches and supports for successful industry strategy formulation (Celik, 2009).

Mc Carty, 1975, (Vignali, 2001) and Walker, (2008: 118133) formulated the concept of the 4Ps - product, price, promotion, and place as marketing mix. However, with particular attention being paid to services marketing in recent years, theorists have identified additional variables which could be added to the 4Ps. Fifield and Gilligan (1996) recognised the following variables as an integral part of the marketing mix process, physical, and people which known as the 7 Ps, on the other hand, Morrison (2002) formulated marketing mix in hospitality industry which is known as the 8Ps (product, price, promotion, place, people, packaging, programming, and partnership). Customer satisfaction in restaurant industry affected by differentiated variables or attributes, such as: price, location, theme/ambience, service level, cuisine, and style, while prestige, friendliness of waiting staff, quality of food, dan ambience are the most important attributes (Kivela, 1997).

Researchers classified dimension of restaurant performance based on some attributes, such as Food Quality, Service Quality, Ambiance, Convenience, Overall/everything included (Dogdubay dan Avcikurt ,2008) ; Responsiveness/service quality, Food Quality/reliability, Physical Design, and Price (Andaleeb and Conway, 2006); Competitive Location, Prices, Food Quality, Customer Service (Abdullah and Rozario (2009). While marketing mix assumed as internal factor controlled by organization, on the other hand, researchers and theorists indentified external factors or uncontrolled factors affected marketing stratetgy of a business organization, known as PESTLE factors, consist of political, economic, sociocultural, technological, legal, and ecological, (Cousin, et al.,
2002: 15), meanwhile, Morrison (2002:21-24) formulated competition, legislation and regulation, economic environment, technology, societal and cultural enviromment, and organizational objectives and resources as external factors. Lai and Rivera, 1990, proposed external factors, consist of competitive environment, demographic trends, economic trends, natural environment, technology trends, political trends, cultural trends, and publics, furthermore, Kotler, et al., (2010:73) classified external factor of a business organization into two major external forces, that will affect its ability to earn profit in the market place, such as: macroenvironment forces (demographic-economic, technological, political-legal, socialcultural) and microenvirontment forces (customers, competitors, distribution channels, supplies). Yu \& Huimin, 2005 , proposed external factor of marketing strategy consist of regional political tension, potential declined of economic, hotel's over provision, competition intensity, meanwhile Bozak $\&$ Tipuric, 2006, formulated tax \& finance regulation, leaders statement and attitude, supply of seasonal workers, local community attitude, environment protection regulation and green association.

\section{RESEARCH METHODS}

To answer the research question posed in the previous page primary data are needed. The data were collected by questionnaires. There were two types questionnaire distributed, first, to the organic restaurant's customers to obtained strengths and weaknesses (internal marketing environment), second, to the restaurant managers to obtained opportunities and threats (external marketing environment). The questionnaire consists of two constructs. The first one is demographic; the second are the performance of each variable with the degree of importance of each variable. Four scala of restaurant's performance level are designed, consist of: 1 (very bad), 2 (bad), 3 (good), 4 (very good), and four scala of degree of important offered, concist of : 1 (not important at all), 2 (less important), 3 (important), and 4 (very important). The questionnaires were distributed in Sanur area for twelve consecutive weeks from August to November 2015. The sample chosen based on personal contacts which we think would ease data availability. There were 7 viable questionnaires completed by restaurant managers and 105 questionaires completed by organic restaurant customers. And to obtain strengths and weaknesses of marketing environment, the concept of the 4 Ps of restaurant industry by Walker, (2008 :118-133) was adopted, consist of product, price, promotion, and place. Considering the rapid growth, wide spread of social media users around of the world, we were replacing the yellow page advertising attributes to social media advertising (facebook, twitter, instagram, yahoo messenger, etc). Place or location indicator consists of visibility, easy access, convenience, curbside appeal, and parking. Product indicators consists of excellent food, organic food, good service, cleanliness, ambiance. Price consists of value for money, credit card acceptance, and competitor's price. Promotion consists of advertising, in-house advertising, advertising appeals, travel guide for free advertising, social media advertising, and mailing list.

Meanwhile, opportunities and threats, or external factors that become variables in this study were Macroenvironment 
forces (demographic-economic, technological, political-legal, socio-cultural) and Microenvirontment forces (customers, competitors, distribution channels, supplies) in Kotler, Bowen, Makes (2010: 73). Internal Factor Evaluation (IFE) and External Factor Evaluation (EFE) were calculated to obtained Internal-External (IE) Matrix or Position Matrix. Next, based on Position Matrix, SWOT Analysis was formulated or conceptualized to propose Grand Strategies and Alternative Strategies. In this case, two models of IE Matrix were used, the first model is IE Matrix developed by McKinsey \& Company at General Electric, is also called as the industry attractivenessbusiness strength matrix (Pearce II and Robinson, 245-247 : 2011), second is IE or Position Matrix introduced by Hsu dan Powers, (2002: 133)

\section{RESULT AND DISCUSSION}

\section{A. Analysis Characteristics of Respondents}

Analysis characteristics of respondents consists of: gender, country of origin, occupation, purpose of visit and frequenly visit to Bali. Result characteristics of 105 person respondents are as follows: 1). Gender: $42,86 \%$ male and 57,14\% female, 2). Countries of origin: Europe, Australia, USA and Asia, 3). Occupation: Employees (34,28\%), Business (18,10\%), Professionals $(25,71 \%)$, Students $(5,71 \%)$, Retired $(10,47 \%)$, and Housewifes $(1,90 \%), 4)$. Purpose of visit : Business $(10,48 \%)$, Pleasure $(71,43 \%)$ and visit friends and relatives $(18,09 \%)$ and 5). Frequently visit to Bali : $1^{\text {st }}$ time $(36,19 \%)$, $2^{\text {nd }}$ time $(20 \%), 3^{\text {rd }}$ time $(23,81 \%)$ and $4^{\text {th }}$ or more $(18,95 \%)$

Others type of respondents is the owners or managers of organic's restaurant in Sanur, where consists of 7 respondents. The opinions of respondents required to obtain data on external variables such as restaurant marketing opportunities and threats.

\section{1) Internal Factors Evaluation (IFE)}

SWOT analysis provides an overview of the business position of organic restaurant in Sanur Tourism Area in the competitive business environment. $4 \mathrm{P}$ strategy analysis are used to determine the position of businesses on aspects of strengths and weaknesses, while the external environment analysis is used to determine aspects of opportunities and threats. In Table 8 and 9, the performance of each indicator (aspect) is indicated by the internal marketing restaurant rating or scores given by respondents. On the other hands, external marketing performance indicators indicated by the average rating or score given by the manager or the owner of an organic retoran. If the average rating indicators of internal and external marketing of this value is above 2.5 (the maximum value 4 ), the position indicator or aspects that are in the category of strength (strength) for internal marketing and category opportunities (opportunity) for external marketing. Meanwhile, if the value is 2.5 to bottom (minimum value is 1.00 ), then the indicator or that aspect in the position of the category of weakness for internal marketing and category of threat for external marketing forces.

To determine the strengths, weaknesses, opportunities, and threats of restaurant's business in Internal-External Factors Evaluation (IFE and EFE) matrix, the position score then obtained from adding up all the result of multiplying the average rating with value's score. To obtain a score of a position of strength and weaknesses, then the average rating multiplied by the value's score that should be added together. This sum of total score combines the strengths with a total score of weaknesess. To determine the score position of opportunities and threats as external restaurant marketing forces, the results then obtained from multiplying the average rating with values's score. This summation incorporates the total score of opportunities with total score of threats.

The four P of organic Restaurant's marketing consist of Place, Product, Price and Promotion aspect.

TABLE I. PLACE ASPECTS OF ORGANIC RESTAURANT IN SANUR

\begin{tabular}{lllllll}
\hline Indicator & $\begin{array}{l}\text { Rati } \\
\mathrm{ng}\end{array}$ & $\begin{array}{l}\text { Mea } \\
\mathrm{n}\end{array}$ & $\begin{array}{l}\text { Degree } \\
\text { of } \\
\text { Importan } \\
\mathrm{t}\end{array}$ & Value & $\begin{array}{l}\text { Mean } \\
\text { X } \\
\text { Value }\end{array}$ & $\begin{array}{l}\text { Cat } \\
\text { a- } \\
\text { gor } \\
\mathrm{y}\end{array}$ \\
\hline Visibility & 366 & 3.49 & 385 & 0.061 & 0.215 & $\mathrm{~S}$ \\
\hline Easy access & 344 & 3.28 & 213 & 0.034 & 0.195 & $\mathrm{~S}$ \\
\hline Convenience & 333 & 3.17 & 350 & 0.056 & 0.178 & $\mathrm{~S}$ \\
\hline $\begin{array}{l}\text { Curbside } \\
\text { Appeal }\end{array}$ & 344 & 3.28 & 312 & 0.050 & 0.163 & $\mathrm{~S}$ \\
\hline Parking & 245 & 2.33 & 365 & 0.058 & 0.136 & W \\
\hline & & & & & & \\
\end{tabular}

TABLE II. PRODUCT ASPECTS

\begin{tabular}{|c|c|c|c|c|c|c|}
\hline Indicator & $\begin{array}{l}\text { Rati } \\
n g\end{array}$ & $\begin{array}{l}\text { Mea } \\
n\end{array}$ & $\begin{array}{l}\text { Degr } \\
\text { ee of } \\
\text { Imp } \\
\text { orta } \\
\text { nt }\end{array}$ & Value & $\begin{array}{l}\text { Mean } \\
\mathrm{X} \\
\text { Value }\end{array}$ & $\begin{array}{l}\text { Cat } \\
\text { a- } \\
\text { gor } \\
y\end{array}$ \\
\hline $\begin{array}{l}\text { Excellence } \\
\text { food }\end{array}$ & 340 & 3.24 & 415 & 0.066 & 0.214 & $\mathrm{~S}$ \\
\hline Organic food & 359 & 3.42 & 385 & 0.061 & 0.210 & $\mathrm{~S}$ \\
\hline Good Service & 343 & 3.27 & 383 & 0.061 & 0.211 & $\mathrm{~S}$ \\
\hline Cleanliness & 336 & 3.20 & 362 & 0.057 & 0.200 & $\mathrm{~S}$ \\
\hline Ambience & 331 & 3.15 & 351 & 0.056 & 0.176 & $\mathrm{~S}$ \\
\hline
\end{tabular}

TABLE III. PRICE ASPECT

\begin{tabular}{|c|c|c|c|c|c|c|}
\hline Indicator & $\begin{array}{l}\text { Rati } \\
n g\end{array}$ & $\begin{array}{l}\text { Mea } \\
n\end{array}$ & $\begin{array}{l}\text { Degr } \\
\text { ee of } \\
\text { Imp } \\
\text { orta } \\
\text { nt }\end{array}$ & Value & $\begin{array}{l}\text { Mean } \\
\mathrm{X} \\
\text { Value }\end{array}$ & $\begin{array}{l}\text { Cat } \\
\text { a- } \\
\text { gor } \\
y\end{array}$ \\
\hline $\begin{array}{l}\text { Value } \\
\text { Money }\end{array}$ & 316 & 3.01 & 250 & 0.040 & 0.120 & $\bar{S}$ \\
\hline $\begin{array}{l}\text { Credit Card } \\
\text { Acceptance }\end{array}$ & 327 & 3.11 & 292 & 0.047 & 0.145 & $\mathrm{~S}$ \\
\hline $\begin{array}{l}\text { Competitors } \\
\text { Price }\end{array}$ & 320 & 3.05 & 278 & 0.044 & 0.135 & $S$ \\
\hline
\end{tabular}

Source: data processing 
TABLE IV. PROMOTION

\begin{tabular}{|c|c|c|c|c|c|c|}
\hline Indicator & $\begin{array}{l}\text { Rati } \\
n g\end{array}$ & $\begin{array}{l}\text { Mea } \\
n\end{array}$ & $\begin{array}{l}\text { Degr } \\
\text { ee of } \\
\text { Imp } \\
\text { orta } \\
\text { nt }\end{array}$ & Value & $\begin{array}{l}\text { Mean } \\
\mathrm{X} \\
\text { Value }\end{array}$ & $\begin{array}{l}\text { Cat } \\
\text { a- } \\
\text { gor } \\
y\end{array}$ \\
\hline Advertising & 319 & 3.04 & 353 & 0.056 & 0.171 & $\mathrm{~S}$ \\
\hline $\begin{array}{l}\text { In-House } \\
\text { Selling }\end{array}$ & 336 & 3.21 & 294 & 0.049 & 0.157 & $\mathrm{~S}$ \\
\hline $\begin{array}{l}\text { Advertising } \\
\text { Appeal }\end{array}$ & 332 & 3.17 & 338 & 0.054 & 0.171 & $\mathrm{~S}$ \\
\hline $\begin{array}{l}\text { Travel Guide } \\
\text { for } \quad \text { free } \\
\text { advertising }\end{array}$ & 265 & 2.54 & 299 & 0.048 & 0.121 & $\mathrm{~S}$ \\
\hline $\begin{array}{l}\text { Social Media } \\
\text { advertising }\end{array}$ & 285 & 2.71 & 334 & 0.053 & 0.144 & $\mathrm{~S}$ \\
\hline Mailing list & 276 & 2.64 & 312 & 0.050 & 0.132 & $\mathrm{~S}$ \\
\hline
\end{tabular}

a) Strengths

Based on the description in Table 1 to 4 , the strength variables of the internal marketing environment of Organic Restaurant in Sanur Tourism Area can be seen in Table 5 underneath.

TABLE V. STRENGTH ASPECTS OF INTERNAL MARKETING ENVIRONMENT

\begin{tabular}{lll}
\hline Indicator & Value & Mean \\
\hline Visibility & 0.0614 & 3.49 \\
Easy access & 0.0340 & 3.28 \\
Convenience & 0.0558 & 3.17 \\
Curbside appeal & 0.0498 & 3.28 \\
Excellence food & 0.0662 & 3.24 \\
Organic Food & 0.0614 & 3.42 \\
Good service & 0.0611 & 3.27 \\
Cleanliness & 0.0574 & 3.20 \\
Ambience & 0.0560 & 3.15 \\
Value for money & 0.0399 & 3.01 \\
Credit card acceptance & 0.0466 & 3.11 \\
Competitors price & 0.0443 & 3.05 \\
Advertising & 0.0563 & 3.04 \\
In-House selling & 0.0490 & 3.21 \\
Advertising appeal & 0.0539 & 3.17 \\
Travel guide for free advertising & 0.0477 & 2.54 \\
Social Media Advertising & & \\
Mailing list & 0.0533 & 2.71 \\
& 0.0498 & 2.64 \\
& & \\
\hline & \multicolumn{2}{c}{ e. }
\end{tabular}

b) Weakness

Table 6 bellow describes the weakness indicator of internal marketing environment.

TABLE VI. WEAKNESS ASPECT OF INTERNAL MARKETING INDICATOR

\begin{tabular}{|c|c|c|}
\hline Indicator & Value & Mean \\
\hline Parking & 0.0584 & 2.33 \\
\hline
\end{tabular}

Internal marketing evaluation factor of organic restaurant in Sanur Tourism area consists of strengths and weaknesses. Table 7 bellow describes the evaluation of internal marketing factors organic restaurant industry.

TABLE VII. INTERNAL FACTORS EVALUATION

\begin{tabular}{|c|c|c|c|}
\hline Internal Factors & Value & $\begin{array}{l}\text { Mea } \\
n\end{array}$ & $\begin{array}{l}\text { Score } \\
\text { (Mean X } \\
\text { Value) }\end{array}$ \\
\hline \multicolumn{4}{|l|}{ A Strengths } \\
\hline Visibility & 0.0614 & 3.49 & 0.2156 \\
\hline Easy access & 0.0340 & 3.28 & 0.1955 \\
\hline Convenience & 0.0558 & 3.17 & 0.1778 \\
\hline Curbside appeal & 0.0498 & 3.28 & 0.1629 \\
\hline Excellence food & 0.0662 & 3.24 & 0.2145 \\
\hline Organic food & 0.0614 & 3.42 & 0.2100 \\
\hline Good service & 0.0611 & 3.27 & 0.2112 \\
\hline Cleanliness & 0.0574 & 3.20 & 0.1998 \\
\hline Ambience & 0.0560 & 3.15 & 0.1764 \\
\hline Value for money & 0.0399 & 3.01 & 0.1201 \\
\hline Credit card acceptance & 0.0466 & 3.11 & 0.1449 \\
\hline Competitors price & 0.0443 & 3.05 & 0.1351 \\
\hline Advertising & 0.0563 & 3.04 & 0.1711 \\
\hline In-House selling & 0.0490 & 3.21 & 0.1573 \\
\hline Advertising appeal & 0.0539 & 3.17 & 0.1709 \\
\hline $\begin{array}{l}\text { Travel guide for free advertising } \\
\text { Social Media Advertising }\end{array}$ & 0.0477 & 2.54 & 0.1212 \\
\hline Mailing list & 0.0533 & 2.71 & 0.1444 \\
\hline Subtotal A & 0.0498 & 2.64 & 0.1315 \\
\hline B Weakness & 0.9416 & & 3.0602 \\
\hline \multicolumn{4}{|l|}{ Parking } \\
\hline \multirow[t]{2}{*}{ Subtotal B } & 0.0584 & 2.34 & 0.1365 \\
\hline & 0.0584 & & 0.1365 \\
\hline 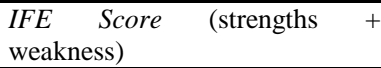 & 1.000 & & 3.1967 \\
\hline
\end{tabular}

g. Source: data processing

\section{2) External Factors Evaluation(EFE)}

Based on data processing, opportunities and threats as external marketing shown in tables 8 and 9 underneath. 
TABLE VIII. OPPOTUNITIES

\begin{tabular}{lllll}
\hline Variables & $\begin{array}{l}\text { Perfor } \\
\text { manc } \\
\mathrm{e}\end{array}$ & $\begin{array}{l}\text { Degr } \\
\text { ee of } \\
\text { Imp } \\
\text { orta } \\
\text { nt }\end{array}$ & Value & Mean \\
& \multicolumn{3}{c}{} & \\
& & & \\
\hline Demographic-Economic & 20 & 24 & 0.130 & 2.86 \\
Technological & 31 & 23 & 0.125 & 4.43 \\
Political-Legal & 19 & 17 & 0.092 & 2.71 \\
Social-Cultural & 23 & 24 & 0.130 & 3.29 \\
Customers & 23 & 23 & 0.125 & 3.29 \\
Competitors & 20 & 26 & 0.141 & 2.42 \\
Supplies & 20 & 23 & 0.141 & 2.86 \\
Total & & & & 2.186 \\
& & & & \\
\hline
\end{tabular}

${ }^{\text {h. }}$ Source: data processing

TABLE IX. THREATS

\begin{tabular}{lllll}
\hline Variables & $\begin{array}{l}\text { Perfor } \\
\text { manc } \\
\text { e }\end{array}$ & $\begin{array}{l}\text { Degr } \\
\text { ee of } \\
\text { Imp } \\
\text { orta } \\
\text { nt }\end{array}$ & & \\
& & & & \\
\hline Distribution channels & 17 & 24 & 0.130 & 2.42 \\
\hline
\end{tabular}

Table 10 bellow describes external factor evaluation of organic restaurant industry in Sanur.

TABLE $X . \quad$ OPPORTUNITIES ASPECT OF EXTERNAL MARKETING INDICATOR

\begin{tabular}{llll}
\hline Variables & Bobot & $\begin{array}{l}\text { Mea } \\
n\end{array}$ & $\begin{array}{l}\text { Skor } \\
\text { Mean X Bobot }\end{array}$ \\
\hline $\begin{array}{l}\text { Demographic-Economic } \\
\text { Technological }\end{array}$ & 0.130 & 2.86 & 0.372 \\
Political-Legal & & & \\
Social-Cultural & 0.125 & 4.43 & 0.554 \\
Customers & 0.092 & 2.71 & 0.249 \\
Competitor & 0.130 & 3.29 & 0.428 \\
Supplies & 0.125 & 3.29 & 0.411 \\
& 0.141 & 2.42 & 0.341 \\
& 0.141 & 2.86 & 0.403 \\
\hline Subtotal : & 0.870 & & 2.758 \\
\hline
\end{tabular}

TABLE XI. THREATS ASPECT OF EXTERNAL MARKETING INDICATOR

\begin{tabular}{|c|c|c|c|}
\hline Variables & Bobot & $\begin{array}{l}M e a \\
n\end{array}$ & $\begin{array}{l}\text { Skor } \\
\text { (Mean X Bobot) }\end{array}$ \\
\hline Distribution channels & 0.130 & 2.42 & 0.315 \\
\hline Subtotal: & 0.130 & & 0.315 \\
\hline $\begin{array}{l}\text { Total EFE (Opportunities } \\
+ \text { Threats) }\end{array}$ & 1.000 & & $\begin{array}{l}(2.758+0.315) \\
=3.073\end{array}$ \\
\hline
\end{tabular}

\section{B. Internal-External Matrix Analysis and SWOT Analysis Diagram Analysis (matrix position).}

1) Internal-External Analysis Matrix (Matrix IE)

Based on the analysis of the environmental aspects of internal and external environment of business marketing organic restaurant in Sanur, the total score of internal factors then pointed at 3,197 points and a total score of external factors scored at 3,073 points. The position of marketing internal environment and the external environment then shown in figure 2 underneath.

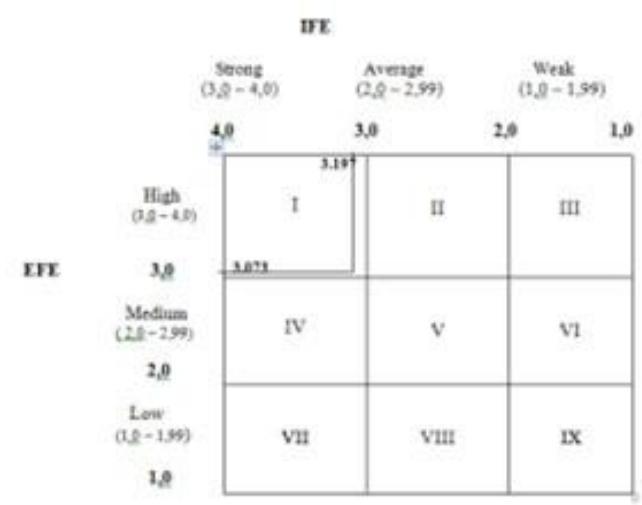

Fig. 1. Internal-Eksternal Matrix (IE Matriks)

Based Internal-External Matrix as shown in figure 1, the position of the organic restaurant in Sanur Tourism Area pointed in cell I. It means, based on the theory of David (2006: 302 ), the strategy that should be implemented by the organic restaurant in Sanur Tourism area is Grow and Develop Strategies (Growth and Build Strategies) composed of market penetration, market development, and product development strategies.

2) SWOT Analysis Diagram (Matrix Position)

To obtain the industry's position based on Hsu and Powers (2002) theory, a calculation then calculated to obtain the difference between internal score (strengths - weaknesses) and external difference score (opportunities - threats) of restaurant industry. Based on data processing, the value of the difference score as follows:

Internal score: $3.0602-0.1365=2.9527=2.9237=$ 2,924. External score: $2758-0315=2443$

The position of the organic restaurant industry can be determined with a SWOT Analysis Diagram as follows: 


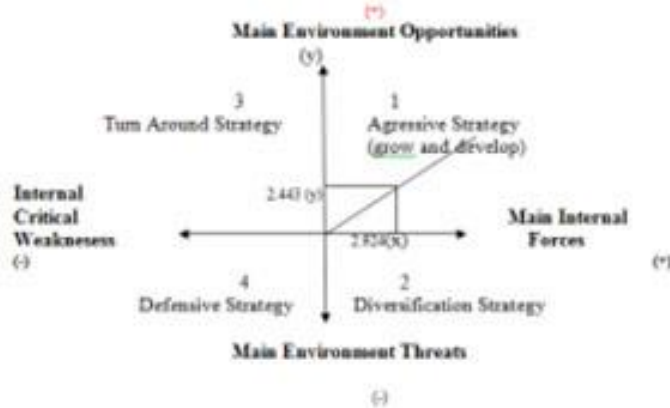

Fig. 2. SWOT Diagram (Matrix Position)

Based on SWOT Diagram, the position of organic restaurant industry Sanur Tourism area pointed in quadrant I, therefore, the proper strategy shoud be develop are "Growth and Build Strategy" consisting of market penetration strategies, market development strategy, and strategy product development. To combine the results of the analysis based on the theory of David (2006: 301) and theory Hsu and Powers (2002: 133), the proper grand strategy should be develop is a market penetration, product development, and market development strategy on a limited basis.

\section{Marketing Strategy Formulation for Organic Restaurant in Sanur Tourism Area.}

In accordance with the model, the formulation of marketing strategies divided into two types of strategies, namely the main strategy or grand strategies and alternative strategies. The main strategy is based on the position of the restaurants on IE Matrix and Matrix position, while the alternative strategy serves as strategies that support grand strategy. The alternative strategy consists of strategies SO (Strength-Opportunities), ST (Strength-Threath), WO (Weakness-Opportunities), and WT (Weakness-Threath).

The grand strategy can be done such as: first, maintaining the price or increase the selling price of products but with the condition, such as; (1) offer better product quality; (2) develop new products (product diversification); (3) increase quality of service; and (4) to improve market access to a wider market on a limited basis; second, by market penetration strategy. Market penetration strategy means to strengthen the business position (increase sales) on an existing market by increasing customer loyalty to the existing products and services and grab a new market segment; third, by product development strategy designed to increase sales by developing and improving the products and services that already exist, or by creating new products that are popular or gaining in popularity.

Based on SWOT Analysis Model, marketing strategy formulation for organic restaurant in Sanur Tourism Area describes as follows:

\section{1) Strengths Opportunities (SO) Strategy}

a) Create new healthy organic food products made from local organic agricultural produce.

b) Reforming the design of the garden with natural ambience to create an attractive restaurant and have certain characteristics

2) Weaknesses Opportunities (WO) Strategy a) Provide price discounts for loyal customers.

b) Offer attractive packages for lunch or dinner for domestic MICE market.

3) Strengths Threats (ST) Strategy

a) Create marketing programs with the theme of Sanur Tourism area as healthy organic culinary destination based on the popularity of art and socio-cultural life.

b) Managing cooperation with the tourism industry and other non tourism organizations to preserve the environment in Sanur, especially the coastal areas and the sea in order to appeal the culinary and gastronomical segment for domestic travelers and foreign tourists.

4) Weaknesses Threats (WT) Strategy

a) Anticipate the negative impact of unfair competition among restaurant's businesses through a selection of integrated permits according to the zoning of Sanur Tourism area.

b) Establish good cooperation between the restaurant business and related industries in marketing regional destinations.

\section{CONCLUSIONS}

Based on the model of SWOT strategy, the qualitative result of each of internal and external factors identified indicate that:

a. Regarding the organic restaurant marketing strategies, most indicators of internal marketing environment are in advantage performances, meanwhile, most indicators of external marketing environment are also in advantage performances.

b. Compared to the threats and weaknesses, the opportunities and strengths of the marketing environment of restaurant industry in Sanur Tourism area are high.

c. According to the IE Matrix result, the grand strategy is the proper grand strategy should be develop is a market penetration, product development, and market development strategy on a limited basis strategy. According to the Position Matrix result, the grand strategy is aggressive or grow and build strategy.

d. Based on SWOT Analysis Matrix, the grand strategy is SO strategy as the implementation of Grow and Build Strategy, meanwhile, the alternative strategies are ST, WO, and WT strategies.

\section{REFERENCE}

Abdullah, D.,N.,M.,A. Rozario,F. (2009). Influence of Service and Product Quality towards Customer Satisfaction: A Case Study at the Staff Cafetaria in the Hotel Industry. World Academy of Science, Engineering and Technology 532009.

Andaleeb, S.,S. Conway,C. 2006. Customer Satisfaction in the Restaurant Industry: An examination of the transactionspecific model. Journal of Service Marketing. The Behrend College, Erie, Pennsylvania,USA. 
Bozac, M.G. dan Tipuric, D. 2006. Top Management's Attitude-Based SWOT Analysis in The Croatian Hotel Industry. EKONOMSKY PREGELD, 57 (7-8) 429474. Cornell University.

Byrne, M. 2002. Understanding Consumer Preferences Across Environmental Marketing Mix Variations. OIKOS University of Newcastle.

Celik, N. 2009. Strategy making with quantified SWOT Approach; A case analysis on tourism industry in Black Sea Region of Turkey. Zonguldak Karaelmas University, Turkey. Departmen of Business Administration.

Cousins, J., Foskett, D., Gillespie, C. 2002. Food and Beverage Management. London: Prentice Hall/Pearson Education

Dev, C. S. And Klein, S 1993. Strategic Alliances in the Hotel Industry. The Cornell Hotel and Restaurant Administration Quarterly, Vol 34: 1. p.42. USA.

Doole, I. and Lowe, R. (2008). International Marketing Strategy: Analysis, development and implementation. Fifth edition. South-Western, Cengage Learning. London.

Dwyer, R. And Tanner, J. (2002), Business arketing, Second edition, International edition, New York : McGrawHill.

Ganjali, S., Shayesteh, K., Mohammadi, H. (2014). Environmental and strategic assesment of ecotourism potential in Anzali Wetland using SWOT analisis. CasianJ. Env. Sci. 2014, Vol. 12 No. 1 pp. 155-164.

Gupta, S., McLaughlin, E., Gomez,M. 2007. Guest Satisfaction and Restaurant Performance. (Analysis of restaurant management). Cornell Hotel \& restaurant Administration Quarterly. Citted from http://www. Entrepreneur .com/ tradejournalsarticle /167388298. html.

Hsu, C. H. C. Dan Powers, T. 2002. Marketing Hospitality. Third Edition. John Wiley \& Son, Inc: New York.

Kivela, J. 1997. Restaurant Marketing Selection and Segmentation in Hong Kong. International Journal of Contemporary Hospitality Management. 9 (3), 116123.

Kotler, P., Bowen, J.T., Makens, J.C. 2010. Marketing for Hospitality and Tourism. Fifth Edition. Pearson. New Jersey, USA.

Menon, A. And menon, A. 1997. 'Enviropreneurial Marketing Strategy: The Emergence of Cooporate Environmentalism as Market Strategy". The Journal of Marketing, Volume 61 No. 1 pp 51-67.

Miandehi, P.M, and Masrouri, M.Y. 2013. Assesment of SWOT Model on Tourism Industry in Sustainable
Development of Rural Areas: case Study on Bandar-E Anzali. World Applied Sciences Journal 21 (3): 455 464, 2013. ISSN 1818-4952.

Miner, T. 1996. Customer - Focused on Menu Marketing. Cornell Hotel and Restaurant Administration Quarterly. June 1996; 37.3 ; ABI/INFORM GLOBAL.

Morrison, A. M. 2002. Hospitality and Travel Marketing. Third Edition. New York: Delmar.

Ottman, J.A., et al. 2011. "Green Marketing Myopia: Ways to Improve Consumer Appeal for Environmentally Preferable Products". Environment Volume 48, Number 5 pp 22-36. Heldref Publication.

Pahl, n. and Richter, A. 2009. SWOT Analysis-idea, methodology and practical approach. GRIN Verlag.

Pearce II, J.A., and Robinson, R.B. (2011). Strategic Management: Formulation, Implementation, and Control. Twelfth Edition. Mcgraw-Hill/Irwin. New York, USA.

Risyamuka, I K. Dan Mandala, K. 2014. Pengaruh Green Marketing Terhadap Keputusan Pembelian Produk Hijau di Restoran Organik, Ubud. Fakultas Ekonomi dan Bisnis Universitas Udayana, Bali, Indonesia.

Risky, K.S. 2013. " penerapan Green Marketing pada Bisnis Produk Kosmetik: Jurnal JIBEKA Volume 7, No. 3 Agustus 2013: 47-53.

Sparks, B., Bowen, J., klag, S. 2003. Restaurant and The Tourist Market. International Journal of Contemporary Hospitality management; 2003 ; 15, 1 ABI/INFORM GLOBAL.USA.

Tsai, C.T. and Horng, J.S. 2011. Exploring Marketing of Culinary Tourism Development in Hong Kong and Singapore: A resource-based theory. JinWen University of Science and Technology, Taipei, Taiwan.

Varadarajan, R. (2010). Strategic marketing and marketing strategy : domain, definition, fundamental issues and foundational premises. Journal of Academic Marketing Science, (2010) 38: 119-40. DOI 10.1007/s1174-0090176-7.

Walker, J., R. 2008. The Restaurant, From Concept To Operation. Third Edition. Jphn Wiley \& Sons. New Jersey. United Stated of America.

Weihrich, H. (1982). The TOWS matrix: Tool for situational analysis. Long Range Planning, 15(2): 54-66

$\mathrm{Yu}$, L. and Huimin, G. 2005. Hotel Reform in China: A SWOT Analysis. Cornell Hotel and Restaurant Administration Quarterly. Vol. 46, no. 2 p 153-169. USA.. 